\title{
Hypocalcemic Crisis Induced by Excessive Milking Running Title: Milking-Induced Hypocalcemic Crisis
}

\author{
Toshihide Yamamoto ${ }^{1, *}$, and Shin-ya lida ${ }^{2}$ \\ ${ }^{1}$ Yao Tokushukai General Hospital, Yao, Osaka, Japan
}

${ }^{2}$ Kagoshima Tokushukai Hospital, Kagoshima, Japan

*Corresponding author: Toshihide Yamamoto, Yao Tokushukai General Hospital, 1-17 Wakakusa-cho, Yao, Osaka, 581-0011, Japan, Tel: 8172993-8501; E-mail: Toshihide.Yamamoto@tokushukai.jp

Received: 13 Sep, 2019 | Accepted: 27 Sep, 2019 | Published: 04 Oct, 2019

Citation: Yamamoto T, lida SY (2019) Hypocalcemic Crisis Induced by Excessive Milking. Int J Endocrinol Metab Disord 5(2): dx.doi. org/10.16966/2380-548X.159

Copyright: (C) 2019 Yamamoto T, et al. This is an open-access article distributed under the terms of the Creative Commons Attribution License, which permits unrestricted use, distribution, and reproduction in any medium, provided the original author and source are credited.

\begin{abstract}
Background: Calcium loss by lactation does not cause hypocalcemia unless mothers have subclinical hypoparathyroidism.

Case report: A 32-year-old woman was an inhabitant of an island located in the south-western region of Japan. She delivered her second boy by Caesarian section in $37^{\text {th }}$ week of gestation in a hospital in the mainland. She began milking the breasts 6 to 7 times a day, yielding ca. $200 \mathrm{ml}$ each times, on $4^{\text {th }}$ post-operative (henceforth, PO day). She left her baby in the hospital and returned her home island on the $7^{\text {th }} \mathrm{PO}$ day. Then, she continued milking the breasts daily and shipped milk to the hospital for her baby. On the $13^{\text {th }}$ PO day, she noticed paresthesia around the mouth and in both hands. Following day, she was admitted in author's hospital for hypocalcemic crisis with intermittent carpopedal spasm and opisthotonos on rare occasions. The initial blood study revealed serum albumin $3.4 \mathrm{~g} / \mathrm{dl}$, calcium $4.6 \mathrm{mg} / \mathrm{dl}$ (reference range, 8.6-10.2), inorganic phosphate $1.6 \mathrm{mg} /$ $\mathrm{dl}$ (reference range, 1.7-2.6). She was given i.v. injections of $8.5 \%$ calcium gluconate, $10 \mathrm{ml}$ and $20 \mathrm{ml}$ successively, which was followed by continuous i.v. infusion of calcium-enriched saline until the $15^{\text {th }}$ PO day. Serum calcium normalized after cessation of milking. Serum intact parathyroid hormone level was $153 \mathrm{pg} / \mathrm{ml}$ (reference range, 10-65) at the time of the admission.
\end{abstract}

Conclusion: The amount of milk mother produces is determined by baby's sucking. When mother is separated from her baby, she might milk the breasts more than the baby's need. Excessive milking has conceivably precipitated hypo-calcemic crisis in the present patient.

Keywords: Hypocalcemic crisis; Parathyroid hormone; Lactation

Abbreviations: C section: Caesarian Section; Br'criptine: Bromo Criptine

\section{Background}

Acute loss of calcium from the body is not considered to be a cause of hypocalcemia [1]. As human milk contains calcium as much as 25.0 $\pm 7.1 \mathrm{mg} / \mathrm{dl}[2]$, lactation, if excessive and not balanced by mobilization of calcium from the bone and augmented intestinal absorption, could produce hypocalcemia. Here we report hypocalcemic crisis of a woman milking the breasts for her baby separated from her.

\section{Case Report}

32-year-old woman was an inhabitant of an island located in the south-western region of Japan. She delivered her second boy by Caesarian section in $37^{\text {th }}$ week of gestation in a hospital in the mainland because of threatened premature labor, the cause of which was not described in the referral letter. On the $4^{\text {th }}$ post-operative day (henceforth, PO day), she began milking the breasts 6 to 7 times a day, yielding ca. $200 \mathrm{ml}$ each time. After she returned her home island on the $7^{\text {th }}$ PO day leaving her baby in the hospital, she continued to milk same amount daily, which was frozen and shipped to the hospital. On the $13^{\text {th }}$ PO day, she became aware of paresthesia around the mouth and in both hands for which she was brought to another hospital. She was thought to suffer from hyperventilation syndrome and treated with sedation and paper-bag without success. Following day, she was transferred to the hospital where one of us (S.I) worked. She was medium sized and normally nourished. She was very apprehensive and complained of acral paresthesia. The blood pressure was 120 mmHg systolic and $80 \mathrm{mmHg}$ diastolic and the pulse 81 per minute. She showed intermittent carpopedal spasm and opisthotonos on rare occasions. The initial studies revealed hemoglobin $10.8 \mathrm{~g} / \mathrm{dl}$, hematocrit $30.6 \%$, white blood cells $7,500 / \mu \mathrm{l}$, platelets $1.6 \times 10^{4} / \mu \mathrm{l}$, serum albumin $3.4 \mathrm{~g} / \mathrm{dl}$, sodium $145 \mathrm{mEq} / \mathrm{L}$, potassium $3.2 \mathrm{mEq} / \mathrm{L}$, chloride $106 \mathrm{mEq} / \mathrm{L}$, calcium $4.6 \mathrm{mg} / \mathrm{dl}$ (reference range, 8.6-10.2), inorganic phosphate $1.6 \mathrm{mg} / \mathrm{dl}$ (1.7-2.6), and magnesium $2.1 \mathrm{mg} / \mathrm{dl}$. The $\mathrm{pH}$ of the arterial gas was 7.44, partial pressure of oxygen and carbon dioxide 107.8 and $29.6 \mathrm{mmHg}$, respectively, and bicarbonate $14.9 \mathrm{mEq} / \mathrm{L}$. The EKG showed the sinus tachycardia with corrected 
QT interval was $0.49 \mathrm{msec}$. The time courses of serum calcium and phosphate and calcium supplementation are illustrated in figure 1 . At outset, she was given i.v. injection of $8.5 \%$ calcium gluconate, $10 \mathrm{ml}$ and $20 \mathrm{ml}$, successively. Then, she was kept on i.v. infusion of saline with $8.5 \mathrm{~g}$ calcium gluconate added in $500 \mathrm{ml}$ saline at a rate of $100 \mathrm{ml}$ per hour until 17:00 hour of the $15^{\text {th }} P O$ day until carpo-pedal spasm had ceased to recur and acral paresthesia weaned. Bromocriptine 75 $\mathrm{mg} /$ day PO was started on the $14^{\text {th }} \mathrm{PO}$ day. The breasts did not get full by the end of the $16^{\text {th }} \mathrm{PO}$ day. Hypocalcemia was observed only when she milked her breasts. Serum intact parathyroid hormone level at the time of the admission was reported in the later period as $153 \mathrm{pg} / \mathrm{ml}$ (normal range, 10-65).

\section{Discussion}

Lactation-associated hypocalcemia is rare: four cases of lactationassociated hypocalcemia were found by pubmed search using hypocalcemia and lactation as keywords into as early as 1967 [3-6]. All of them were proved to have occult hypoparathyroidism as a cause of hypocalcemia. Calcium loss into milk is thought to be compensated in lactating mothers. Hypocalcemia is ameliorated in patients with hypoparathyroidism presumably mediated either by prolactinmediated calcium homeostasis [7] or by augmented sensitivity to calcitriol as suggested by decreased requirement of calcitriol in lactating patients with hypoparathyroidism [8-10]. This patient responded to hypocalcemia by augmented secretion of parathyroid hormone. Milk of Japanese mother reportedly contains $25 \mathrm{mg} / \mathrm{dl}$ of calcium [2]. As the present patient milked $200 \mathrm{ml}$ six to seven times a day, calcium lost in milk is calculated as $300-350 \mathrm{mg}$ per day. Suppose 2-week-old neonate sucks $500 \mathrm{ml}$ of milk a day, which contains 125 mg of calcium. Hypocalcemia was observed only when she milked

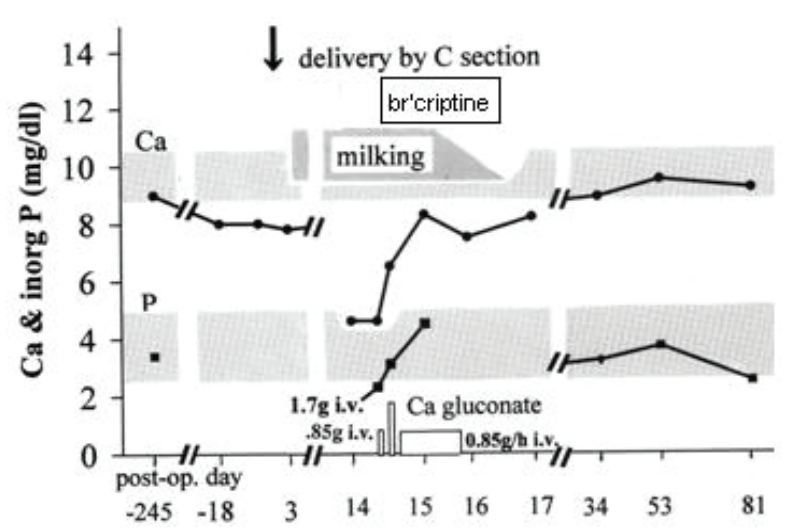

Figure 1: Serial changes of serum calcium and inorganic phosphate before, during, and after lactating period.

The time course of calcium concentrations is shown by bold lines connected by closed circles and that of phosphate concentrations shown by bold lines connected by closed squares. The reference ranges of calcium and phosphate are shown by gray bands. the breasts. Hence, hypocalcemic crisis is presumably precipitated by excessive milking. Two calcium levels before Caesarian section were below the reference range. Subclinical hypovitaminosis $\mathrm{D}$ before the surgery might have contributed to the development of hypocalcemic crisis, which could not be proved without 25-hydroxy Vitamin D measurement (not obtained for cost uncovered by health insurance).

\section{Conclusion}

The amount of milk mother produces is determined by baby's sucking. When mother is separated from her baby, she milked the breasts more than the baby's need. Excessive milking may precipitate hypocalcemic crisis. When baby is separated from mother, mother milking for baby has to be instructed to be watchful of hypocalcemia manifested by acral paresthesia.

\section{Acknowledgements}

The authors declare no conflict of interest in this case report. The consent to publish this account could not be obtained as the patient was lost from follow-up.

\section{References}

1. Fukumoto S, Namba N, Ozono K, Yamauchi M, Sugimoto T, et al. (2008) Causes and differential diagnosis of hypocalcemiarecommendation proposed by expert panel supported by ministry of health, labor and welfare, Japan. Endocrine J 55: 787-794.

2. Yamawaki M, Yamada M, Kan-no T, Kojima T, Kaneko T, et al. (2005) Macronutrient, mineral and trace element composition of breast milk for Japanese women. J Trace Elem Med Biol 19: 171-181.

3. Bernstein A (1967) Idiopathic hypoparathyroidism manifesting after lactation. Postgrad Med J 43: 422-424.

4. Harrod RA, Kennedy PG (1982) Hypocalcaemia-induced epilepsy during lactation. Br Med J (Clin Res Ed) 285: 607-608.

5. Tami TA, Parker GS, Griggs JA, Coddington CC $3^{\text {rd }}$ (1990) Postthyroidectomy hypocalcemia during lactation. Ear Nose Throat J 69: 773-774.

6. Durst R, Meirovitz A, Gross D, Kolker O, Muszkat M (2002) Postpartum hypocalcemia: idiopathic hypoparathyroidism manifested early in lactation. J Endocrinol Invest 25: 561-563.

7. Rude RK, Haussler MR, Singer FR (1984) Postpartum resolution of hypocalcemia in a lactating hypoparathyroid patient. Endocrinol Jpn 31: 227-233.

8. Cundy T, Haining SA, Guilland-Cumming DF, Butler J, Kanis JA (1987) Remission of hypoparathyroidism during lactation: evidence for a physiological role for prolactin in the regulation of Vitamin $D$ metabolism. Clin Endocrirol (Oxf) 26: 667-674.

9. Caplan RH, Wickus GG (1993) Reduced calcitriol requirements for treating hypoparathyroidism during lactation. A case report. J Reprod Med 38: 914-918.

10. Sweeney LL, Malabanan AO, Rosen H (2010) Decreased calcitriol requirement during pregnancy and lactation with a window of increased requirement immediately post partum. Endocr Pract 16: 459-462. 